\title{
A Descriptive Study of the Effectiveness of Parenting Against Early Childhood Social Development
}

\author{
Farny Sutriany Jafara, Syamsuddin ${ }^{\mathrm{a}}$, Sukaena ${ }^{\mathrm{b}}$

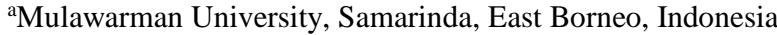 \\ bWidya Gama Mahakam Samarinda University, Samarinda, East Borneo, Indonesia \\ Corresponding e-mail: farny_sutriany@yahoo.co..id
}

\begin{abstract}
Education and guiding the child will be more successful if done with affection and providing a model. The study aims to describe the effectiveness of parenting adopted by parents in the home toward social children development. Type of the research is a descriptive qualitative methods. Participant of this research are 5 people that is in accordance with the technique of snowball sampling. It was concluded that parenting parents had very important influence on the development of social. While the dominant applied parenting is parenting permissive.
\end{abstract}

Keywords: parenting, social development, early childhood

\section{INTRODUCTION}

Early childhood education is education that creates children to be able to socialize with the environment and be able to develop various potentials. Therefore the educator has to understand the suitable education for children to prepare them in live in their environment. Besides teachers in the school, parents are educators who give much influence for early childhood education, since early childhood tend to imitate which is done by people in their environment. This proves that family environment has an important influence in growing and developing children. Home environment is the first environment for children. By increasing age, children will recognize their peers outside in the home or from their neighborhood.

Furthermore, we will go to the school environment, where they will know their peers, adults and tasks at school. Based on the development task, preschool children should be prepared in order to enter the world of school happily the children attitude toward school has very influential on his success in adjusting the school environment.

Preparation for the school must be prepared from early age in a manner that is fun for children. It is need a support of wide range of environments, especially family environment namely parents.

Besides teachers in the school, parents are educators who have an important role in developing various aspects of children development. In addition, parents also have an obligation to understand and identify various behavioral patterns of each child. It can be seen from social development of children, such as attention to how children get along with their peers, the language, social behavior, which is showed that how children respect to other person, friendly, courteous and has a value which is suitable with cultural society.

Many facts are visible from observations result, researchers found that teachers and parents often judge a child's development just by looking at the motorist and speech competency, even though there are many other skills that need to be developed as attention to how social attitudes of children toward friends who are learning, such as books seized the assignment of teachers, the attitude of a child playing with his friends, the way children adapt to new environments, teaches self-reliance on children and pay attention to how the child's attitude while fighting over a toy, etc. In this case teachers and parents need to understand the parenting of the 
child's social development so that children can socialize well.

Besides problem above, the researchers also found that most of parents in Mutiara Hati kindergarten always waiting children in school even sit directly in the classroom with their children during the class. This proves that most of parents in Mutiara Hati kindergarten who do not understand how appropriate parenting style for child development.

Then, here also seen a lack of collaboration between the school and parents. If the problem still persists continuously, then the learning process will be interrupted and social development of children will also be increasingly unfavorable. Parenting style of a child can give an enormous influence on the social development of children. The types of parenting are authoritarian, permissive and democratic. If parents use inappropriate parenting style, it may interfere with children social development, such as parents who are always spoiling her child, this can lead to bad behavior in children, such as: self-centered, spoiled, like annoy your friends at school, aggressive, lie, cheat, dependency, rebellious, selfish, and others.

The hard parents (authoritarian) in educating their children, it is also an incorrect parenting styles by parents to their children. If parents are too authoritarian in educating children, it will be harmful to the social development of children, such as children become timid, shy, difficult to adapt to other people, ashamed to reveal something, even it will be able to break the creativity and talents and interests of children.

While permissive parenting that only let and self-surrender to what children do. Thus the child will grow up with no direction because of the 8 lack guidance from parents. In contrast to democratic parenting which is always to educate children with heart and loving so that children have a better future. The effectiveness of parental parenting styles of children can be seen from the way children behave in their daily life.

Especially from the social behavior of the child, if the parents have to get children to teach good behavior, then behavior exhibited by children is also good behavior. And vice versa, if the parent gives the child habituation social behavior which is not good, then the child will imitate the behavior too. Due to the social development is a stage of children social behavior in following social maturity and interaction with the environment.

This study was done to improve parenting parents in educating children, especially in improving the social behavior of children so that children can grow and develop in accordance with the mndevelopmental stages as described in the UN Convention on the Rights of the Child which has also been validated by the Government of Indonesia in 1990, rights child rights are also embodied in the law No. 23 of 2002 on the protection of children, emphatically explained that every child has the right to live, grow, develop and participate fairly in accordance with human dignity, as well as protection from violence and discrimination. The right to grow this includes the right to obtain guidance and education in ways that properly, so that the full potential of the child can develop optimally, (Edsa, 2010: vi). The research focus is on the effectiveness of parenting parents to the social development of children at home, especially to families whose child schools at Mutiara Hati Kindergarten seen from authoritarian parenting, permissive parenting and democratic parenting.

\section{RESEARCH METHODOLOGY}

This research is a descriptive study using a qualitative approach. This qualitative descriptive was applied to collect data about parenting model given by parent in home. According to Surakhmad (1998:139), descriptive research is a research stating and interpreting the exits data, for example the experienced situation, the correlation of activities, opinion, visible attitude, or the process working, appear different, the visible tendency, the provocative conflict and etc. Qualitatively, this research aims to descript the effectiveness of learning process of parenting for early child's social development at Mutiara Hati Kindergarten.

Researcher conducted this research by listening carefully and observing each behavior related to aims of research. Then, researcher tap related behavior mainly about child's social development. Bogdan dan Biglen in Moleong (2005: 132) explain that using participant for researcher in order to in short time can gain many information. The research participants are five parents of student enrolled in Mutiara hati Kindergarten.

The background of the parents generally are housewives and traders. The key participant for this study is the researchers themselves and some parents of children in Mutiara Hati Kindergarten. In determining the information this study was done by using snowball sampling. In analyzing the data, researchers used qualitative data. Which form of observations execution of research conducted descriptively. Such as: observation sheet parenting of children parents and learners. Through home visits researchers looked forms parenting of parents 
toward their children, field notes and interview format.

The results of observation were analyzed by looking at the actions of parents at home to the social development of children whose school in Mutiara Hati Kindergarten. It aims to look at the extent to which any form of treatment of parent to a child's social development. Field notes analyzed with regard to weakness and kindness of the parenting of parents toward their children.

Based on data analysis technique that researchers do then technique validation data from this study is using triangulation techniques. Sugiyono (2009: 330), states that the technique of triangulation is a data collection techniques are combining of various data collection techniques and data sources that already exist. Thus, a technique performed for validating the data that is from the Snowball sampling technique, literature studies, field studies, interviews, and documentation then triangulation techniques in order to obtain additional data.

\section{FINDING AND DISCUSSION}

The result of interview and observation about punishment indicator is found that participant ES, (29 November 2015: 16.00), always give punishment to his children for every mistaken and kinds of punishment is isolating his children in bedroom until children promising to did not repeat the mistake again in other time.

Participant EW, 14 December 2015: 13.00, always give punishment by pretending getting sick until his child become anxiety and promise to stop for doing mistake any more. Participant YY (3 December 2015: 16.00) only give punishment by intimidate her to inter in well but physical punishment to every mistake done by her children. Participant EM (28 November 2015) punish her child using pinch and reduce money to buy something. From this information, we can know that EW and ES tend to authoritarian while YY, HW and EM tend to permissive.

Permissive parenting is style that more fax in caring and guidance child especially in discipline. This will cause child growth up without direction, less responsibility and will be difficult in making friend and socialization.

Based on the observations and the results of interviews with participants on the indicator gives less control that the participant EW and YY (December 4, 2015) less control to children when playing outside the house, but the condition asked permission where they want to play, in contrast to the participant HW, ES and EM always gives control to the child when the child is playing outside the house because they are worry something that are not desirable will happen, one of which was hit by a motorcycle. Thus it can be seen that the participant EW and YY tend the permissive parenting, while the participant HW, ES and EM is democratic parenting.

Democratic style is based on parent's understanding and respectful to their child. Parent applies a rule suitable with age development phase of child. Parent also respect to good discipline and behavior. In line with Baumrind's opinion in Yusuf (2001), parent have to stimuli and motivate child to express idea and ask something, gives explanation about impact for bad and good behavior, and internalize that child have potency.

Based on the observations and the results of interviews with participants on indicators introduce the culture of queuing that participants HW (December 13, 2015), EW (December 14, 2015), ES (Wednesday, November 30, 2015: 16.00) and YY (December 4, 2015) were both not introduce culture queued to the child if the wait in line, but it's up to the child alone. Unlike the participant EM (December 16, 2015) is always introducing queuing culture to children such as teaching children to take turns using toys at school. Thus it is known that the participant HW, EW, ES and YY inclined at .Its be permissive parenting. While participants EM tends to be on parenting democratic, emphasizing explanations and meanings that underlie the regulations, an award it in accordance with the opinion of Suryadi (2006: 72), states that democratic parents, especially praise, given generously when a child does the right thing or trying to do exactly what is expected.

In this section will be presented explanation of the results. The focus of the discussion is Effective Parenting Parents toward Early Childhood Social Development in Mutiara Hati kindergarten. Through a descriptive study with qualitative approach, the researchers will describe the discussion on data analysis using data collection techniques based on the guidelines for observation, interviews and documentation on each of the parents at home. While conducting research at home, participants did not know that the researchers make observations to see the effectiveness of parenting parents toward the child's social development. Based on these observations, the researchers looked at the various forms of parenting which is parents applied in educating their children at home.

Based on research conducted in the field, the researchers find answers from the study showed that 
the most dominant parenting that is parents applied in home whose school her child in Mutiara Hati kindergarten for the social development of children tend to be the permissive parenting. It is appropriate in the opinion of Shapiro (1999: 27-28), stating that permissive parent, tried to accept and educate children as possible, but tends to be very passive when it came to the issue of defining the limits or respond to non-compliance. Permissive parent are not so demanding, also did not set a clear goal for his son, and convinced that children should develop in accordance with their natural tendencies. Parents who foster this pattern let the child do what he wants. As a result, children never learn self-control their own behavior and always look forward to his goal, which tend to be egocentric, not obey the rules, and difficulties in relationships with peers (peer).

Baumrind in Yusuf (2001: 52), states that parents are permissive, 'acceptance' is high, but low control, then give freedom to the child to express impulse / desire. According Baumrind in Santrock (2007: 167) states that there are two forms of permissive parenting, namely: a) care which neglect, is a style of parenting where it is involved in a child's life. Children who have parents which ignore the feeling that the other aspects of the lives of older people is more important than themselves, b) parenting obey, is a parenting style which very involved with the children, but not too demanding or control of the child.

In the research findings on indicators of punishment that the participant ES (November 29, 2015: 16.00) always gives punishment to their children any made a mistake and the punishment that it provides a child is locked in a room until the child does not repeat his mistakes. Participant EW (December 14, 2015: 13:00) always give punishment by pretending getting sick until his child become anxiety and promise to stop for doing mistake any more. Only give punishment by intimidate her to inter in well but physical punishment to every mistake done by her children. On the other hand participant EM (28 November 2015) provides for punishment of children each child made a mistake with the penalty pinch the hip and reduce the children money. Thus it can be seen that the participant HW and ES prone to authoritarian parenting while the participant YY, EW, and EM is more likely at the permissive parenting.

Parenting tender (permissive) is on research findings participant HW indicators for less control that the participant EW and YY (December 4, 2015) failed to give control to children when playing outside the house, but the condition asked permission to want to play where, in contrast to the participant HW, ES and EM always give control to the child when the child is playing outside the house for fear the child will experience things that are not desirable, one of which was hit by a motorcycle.

Thus it can be seen that the participant EW and YY tend the permissive parenting style, while the participant HW, ES and EM is more prone to democratic upbringing. In accordance with the opinion of Hart, et al in Santrock (2007: 168) states that nurture democratic (authoritative) tends to be a parenting style most effective, the parents' reason are authoritative applying the right balance between control and autonomy, giving children the chance to establish independence while provide standards, limits, and guidance they need. Authoritative parents are more likely to involve children in activities to give and receive verbal and allows children to express opinions, warmth and involvement of parents given by authoritative parents make children more receptive influence of parent.

Democratic parenting style, with indicator introduction of cultural queue, was found that the participant HW, EW, ES and YY not introduce queuing culture to children, but it is up to the child alone. Unlike the EM participant who always introduce culture to the child if the queue waiting for their turn, like to teach children to take turns in using a toy. Thus it is known that the participant HW, EW, ES and YY prone to parenting permissive. While participants EM more likely on parenting democratic. Baumrind opinion in accordance Santrock (2007: 167) that democratic parenting is parenting that encourage children to be independent but still applying the limits and controls on the actions of the child. Verbal give and take action is possible and parents are warm and caring towards children

Many researchers who found that permissive parenting is that parents always spoil the child in the form of care for children in the classroom while being learned until the lesson is complete without a thought would disrupt student learning activities. Egocentric child is a child will scream loudly and cried when one wish is not fulfilled then pull out words that are not reasonable to say such foul language and so on. While parenting is effective for social development of children that should be applied to the elderly at home, especially in the Mutiara Hati kindergarten is a democratic parenting style. Effective parenting is recognized for creating independent child, and the courage to express something creative, responsible, spirit, full of smiles, endeared everyone so have a lot of friends. Children 
who get educated with democratic parenting role model and affection.

\section{CONCLUSIONS}

Overview of parenting to the social development of early childhood, according to a study in Mutiara Hati Kindergarten can be seen as follows:

Authoritarian parenting, it is known that parents who use authoritarian parenting of children, thus predisposing the child will become timid, reclusive, closed to hang out, it is difficult to adapt to peers, always feel inferior in the eyes of a group of playmates, less bold in expressing opinions, it is difficult to reach ideals, always obedient to the commands of old people so that social development of children is not good. Authoritarian parents tend to give corporal punishment of children, so that the education given to children gives poor effectiveness, especially the social development of the child. It can be over and become a problem to the social development of children, among others: the child becomes withdrawn, aggressive, frustrated, deceitful, and the emergence of feelings of revenge in children, because they feel hurt and do not receive the treatment of parents, so that the child has problems of social development. Authoritarian parents tend to give less good effectiveness to the social development of children, there is the possibility of parenting is parenting that is hereditary so your child will likely mimic the pattern of care to the next generation.

Overview of permissive parenting style is known that parents who use permissive parenting causes children tend to be less self-contained, selfcentered, less concerned about the environment and other people because children never given advice to love and respect others. Children with permissive parenting style also has a tendency to become a spoiled child, it is because the child feels less noticed by the parents so that the child will look for attention and affection from other environments, such as at the child's school will always whining to the teacher.

Parents with democratic parenting make children tend to be more independent, achievement, able to find creative ideas in accordance with the level of development, always the spirit in conducting, will be successful, have ideals, respect for parents and others, has an attitude sympathy and empathy for others, has many friends, be bold in expressing opinion, feeling safe because they always get the attention and direction of life is clear, so that children from families tend to have a democratic responsibility and optimistic future.

\section{REFERENCES}

Edsa, M.P.I. (2010). Anakku Penyejuk Hatiku. Bekasi: Pustaka Tarbiatuna.

Moleong, J.L. (2005). Metodologi Penelitian Kualitatif. Bandung: PT Remaja Rosda Karya.

Santrock, J.W. (2007). Perkembangan Anak, Jilid 2. Jakarta: Erlangga.

Shapiro, L.E. (1999). Mengajarkan Emotional Intelegence Pada Anak. Jakarta: Gramedia.

Sugiyono. (2009). Metode Penelitian Pendidikan. Bandung: PT. Remaja Rosda Karya.

Surakhmad, W. (1998). Pengantar Penelitian Ilmiah. Bandung: PT. Remaja Rosda Karya.

Suryadi, T. (2006). Kiat Jitu Dalam Mendidik Anak. Jakarta: Gramedia.

Yusuf, S. (2001). Psikologi Perkembangan Anak dan Remaja. Bandung: PT Remaja Rosda Karya. 